\title{
Conceptual Evaluation for the Installation of Treatment Capability for Mixed Low-Level Waste at the Nevada National Security Site
}
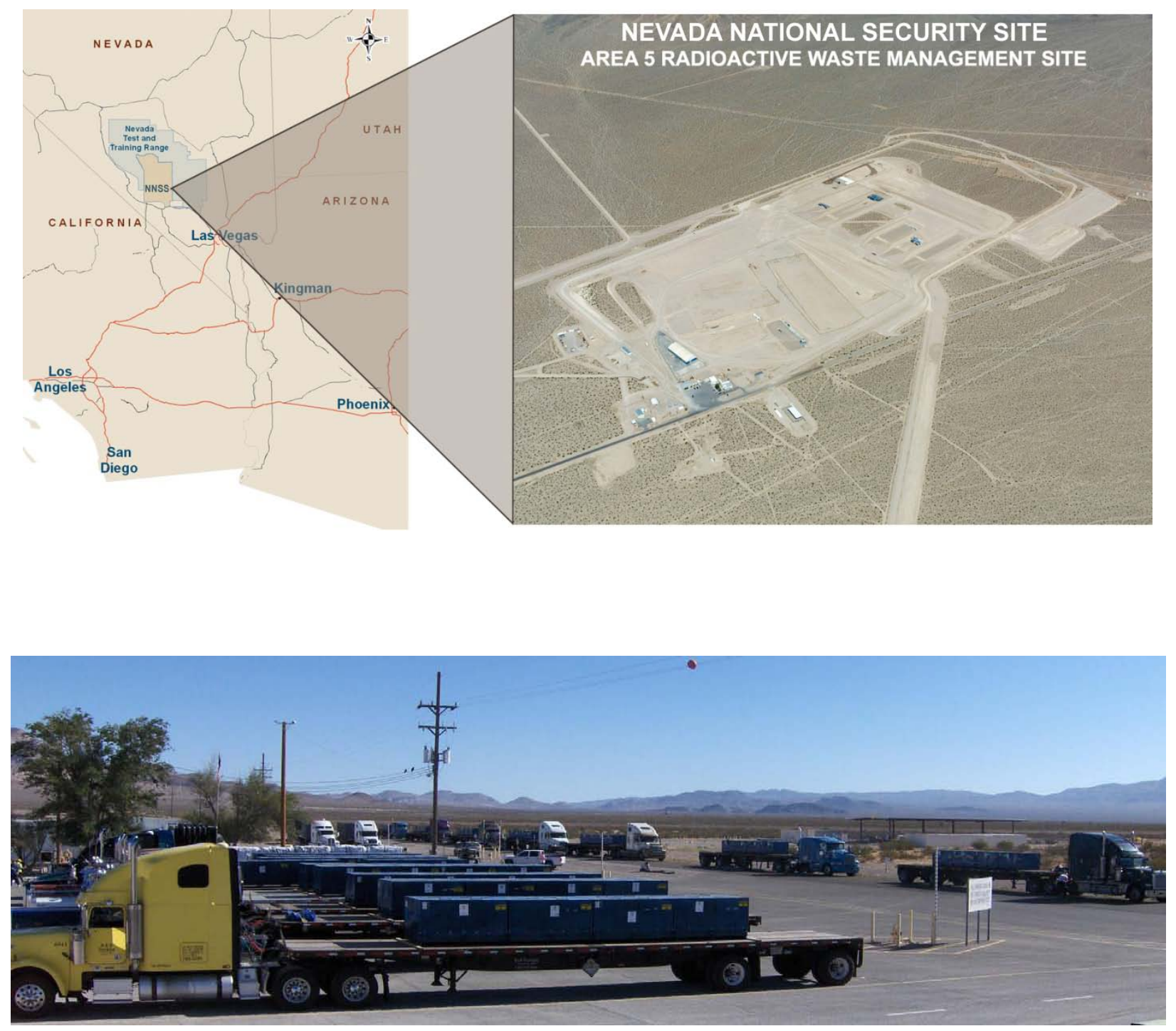


\title{
DISCLAIMER
}

Reference herein to any specific commercial product, process, or service by trade name, trademark, manufacturer, or otherwise, does not necessarily constitute or imply its endorsement, recommendation, or favoring by the U.S. Government or any agency thereof.

\section{AVAILABILITY STATEMENT}

Available for sale to the public from-

\author{
U.S. Department of Commerce \\ National Technical Information Service \\ 5301 Shawnee Road \\ Alexandria, VA 22312 \\ Telephone: 800.553.6847 \\ Fax: 703.605.6900 \\ E-mail: orders@ntis.gov \\ Online Ordering: http://www.ntis.gov/help/ordermethods.aspx
}

Available electronically at http://www.osti.gov/bridge

Available for a processing fee to U.S. Department of Energy and its contractors, in paper, from-

U.S. Department of Energy

Office of Scientific and Technical Information

P.O. Box 62

Oak Ridge, TN 37831-0062

Telephone: 865.576.8401

Fax: 865.576.5728

E-mail: reports@adonis.osti.gov 


\section{Conceptual Evaluation for the Installation of Treatment Capability for Mixed Low-Level Waste at the Nevada National Security Site}

Prepared for

National Security Technologies, LLC

Las Vegas, Nevada 



\section{EXECUTIVE SUMMARY}

National Security Technologies, LLC, initiated an evaluation of treatment technologies that they would manage and operate as part of the mixed low-level waste (MLLW) disposal facilities at the Nevada National Security Site (NNSS). The NNSS Disposal Facility has been receiving radioactive waste from the U.S. Department of Energy (DOE) complex since the 1960s, and since 2005 the NNSS Disposal Facility has been receiving radioactive and MLLW for disposal only. In accordance with the Resource Conservation and Recovery Act (RCRA), all mixed waste must meet land disposal restrictions (LDRs) prior to disposal. Compliance with LDRs is attained through treatment of the waste to mitigate the characteristics of the listed waste hazard. Presently, most generators utilize commercial capacity for waste treatment prior to shipment to the NNSS Disposal Facility. The objectives of this evaluation are to provide a conceptual study of waste treatment needs (i.e., demand), identify potential waste treatment technologies to meet demand, and analyze implementation considerations for initiating MLLW treatment capacity at the NNSS Disposal Facility.

A review of DOE complex waste generation forecast data indicates that current and future Departmental demand for mixed waste treatment capacity will remain steady and strong.

Analysis and screening of over 30 treatment technologies narrowed the field of treatment technologies to four:

- Macroencapsulation

- Stabilization/microencapsulation

- $\quad$ Sort and segregation

- Bench-scale mercury amalgamation

The analysis of treatment technologies also considered existing permits, current the NNSS Disposal Facility infrastructure such as utilities and procedures, and past experiences such as green-light and red-light lessons learned.

A schedule duration estimate has been developed for permitting, design, and construction of onsite treatment capability at the NNSS Disposal Facility. Treatment capability can be ready in 20 months. 


\section{TABLE OF CONTENTS}

1. INTRODUCTION AND BACKGROUND INFORMATION …................................................... 1

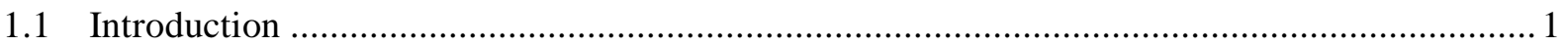

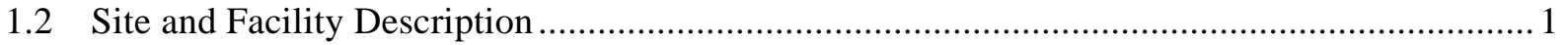

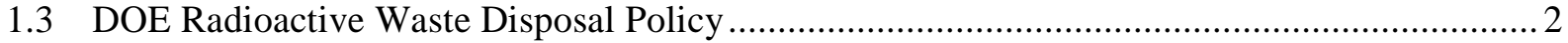

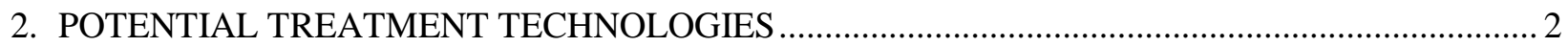

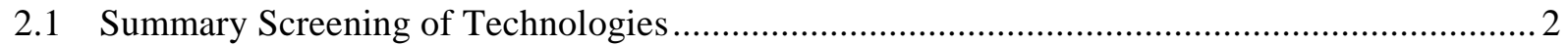

2.2 Macroencapsulation, Stabilization, and Microencapsulation ................................................ 3

3. MLLW VOLUMES BY TECHNOLOGY EVALUATION ............................................................ 4

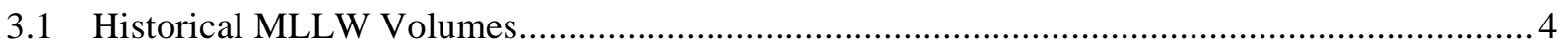

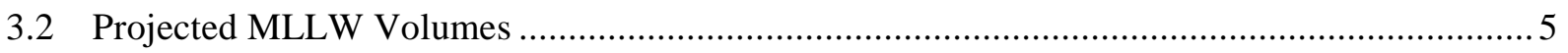

4. SELECTION OF POTENTIAL TREATMENT TECHNOLOGIES …............................................ 6

4.1 Treatment Activities from Historical Experience ................................................................. 6

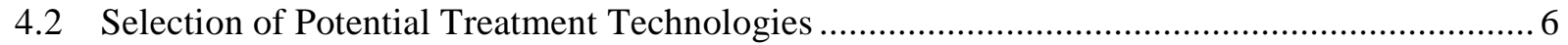

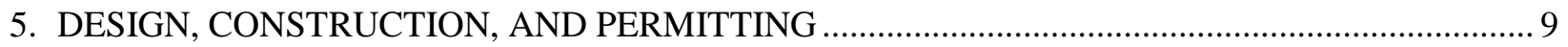

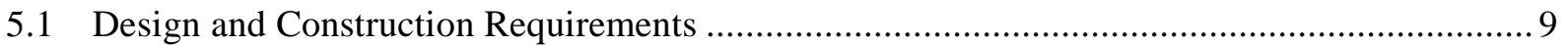

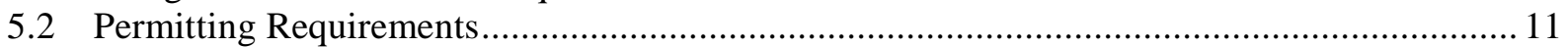

5.3 Estimated Design, Permitting, and Construction Schedule .................................................. 12

APPENDIX A: COMBINED PROJECTED WASTE VOLUMES .................................................... A-1 


\section{TABLES}

Table 1. Potential LDR Treatment Technologies for MLLW and Debris ............................................. 3

Table 2. Historical and Projected MLLW Volumes for the Two Major Treatment Types........................... 4

Table 3. Historical Treatment Types for MLLW Disposed at the NNSS Disposal Facility 2006-2009......5

Table 4. Projected Waste Volumes for MLLW to be Disposed at the NNSS Disposal Facility 2010-2016

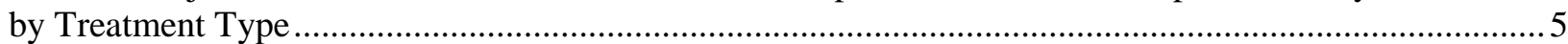

Table 5. Design Requirements Utilizing Existing Facilities at the NNSS Disposal Facility..................... 11

\section{FIGURES}

Figure 1. Nevada National Security Site Disposal Facility................................................................... 2 


\section{ACRONYMS}

$\begin{array}{ll}\text { CFR } & \text { Code of Federal Regulations } \\ \text { DHP } & \text { Drum Holding Pad } \\ \text { DOE } & \text { U.S. Department of Energy } \\ \text { EPA } & \text { U.S. Environmental Protection Agency } \\ \mathrm{ft} & \text { foot } \\ \mathrm{ft}^{3} & \text { cubic foot } \\ \mathrm{HDPE} & \text { High density polyethylene } \\ \text { LDPE } & \text { Low density polyethylene } \\ \text { LDR } & \text { Land Disposal Restriction } \\ \text { LLW } & \text { low-level waste } \\ \text { MLLW } & \text { mixed low-level waste } \\ \text { NDEP } & \text { Nevada Division of Environmental Protection } \\ \text { NNSS } & \text { Nevada National Security Site } \\ \text { RCRA } & \text { Resource Conservation and Recovery Act } \\ \text { RTR } & \text { Real-Time Radiography Building } \\ \text { SIS } & \text { Sprung Instant Structure } \\ \text { SPSS } & \text { Sulfur Polymer Stabilization/Solidification } \\ \text { TP } & \text { TRU Pad } \\ \text { TPCB } & \text { TRU Pad Cover Building } \\ \text { TRU } & \text { transuranic } \\ \text { VERB } & \text { Visual Examination and Repackaging Building }\end{array}$




\section{INTRODUCTION AND BACKGROUND INFORMATION}

\subsection{INTRODUCTION}

The objective of this report is to provide a preliminary evaluation of potential treatment technologies and their installation at the Nevada National Security Site (NNSS) Disposal Facility, including treatment technology types and permitting timeframes. The treatment technologies under consideration are those technologies that could be used to treat U.S. Department of Energy (DOE) generated mixed low-level waste (MLLW) in order to meet Resource Conservation and Recovery Act (RCRA) Land Disposal Restrictions (LDRs) prior to landfill disposal at the NNSS Disposal Facility.

To achieve this preliminary evaluation, the report first looked at the potential treatment technologies set forth in the regulations and those known to be necessary through historical experience at the NNSS Disposal Facility. The evaluation then looked at the volumes, types of wastes, and their treatments that have historically been used prior to disposal at the NNSS Disposal Facility, as well as the volumes/wastes/treatments projected to be disposed at the NNSS Disposal Facility. This comparison found that the viable treatment options would be:

- Macroencapsulation

o Portland Cement

o UltraTech Macro boxes ${ }^{\circledR}$

- Stabilization/Microencapsulation

o Portland Cement

- $\quad$ Sort and Segregation

- Bench-scale Mercury Amalgamation

To estimate the timeframe for implementing these technologies, the existing permits and existing facilities at the site were taken into consideration. It was estimated that the permitting, design, and construction activities could take approximately 20 months to complete.

Supporting documentation for this conceptual treatment capability report is included in Appendix A, “Combined Projected Waste Volumes.”

\subsection{SITE AND FACILITY DESCRIPTION}

The NNSS Disposal Facility is a 1,200 square mile federal reservation located 60 miles north of Las Vegas, Nevada. Historically, the NNSS Disposal Facility has been used primarily for weapons testing and development. Low-level waste (LLW) and MLLW generated from onsite development activities have been treated and disposed at the NNSS Disposal Facility.

Nearly all mixed waste shipped for disposal in the mixed waste disposal unit is from offsite DOE generators, with only a very small fraction coming from onsite mixed waste generators.

Figure 1 provides an aerial view of the waste disposal complex on the NNSS Disposal Facility. 


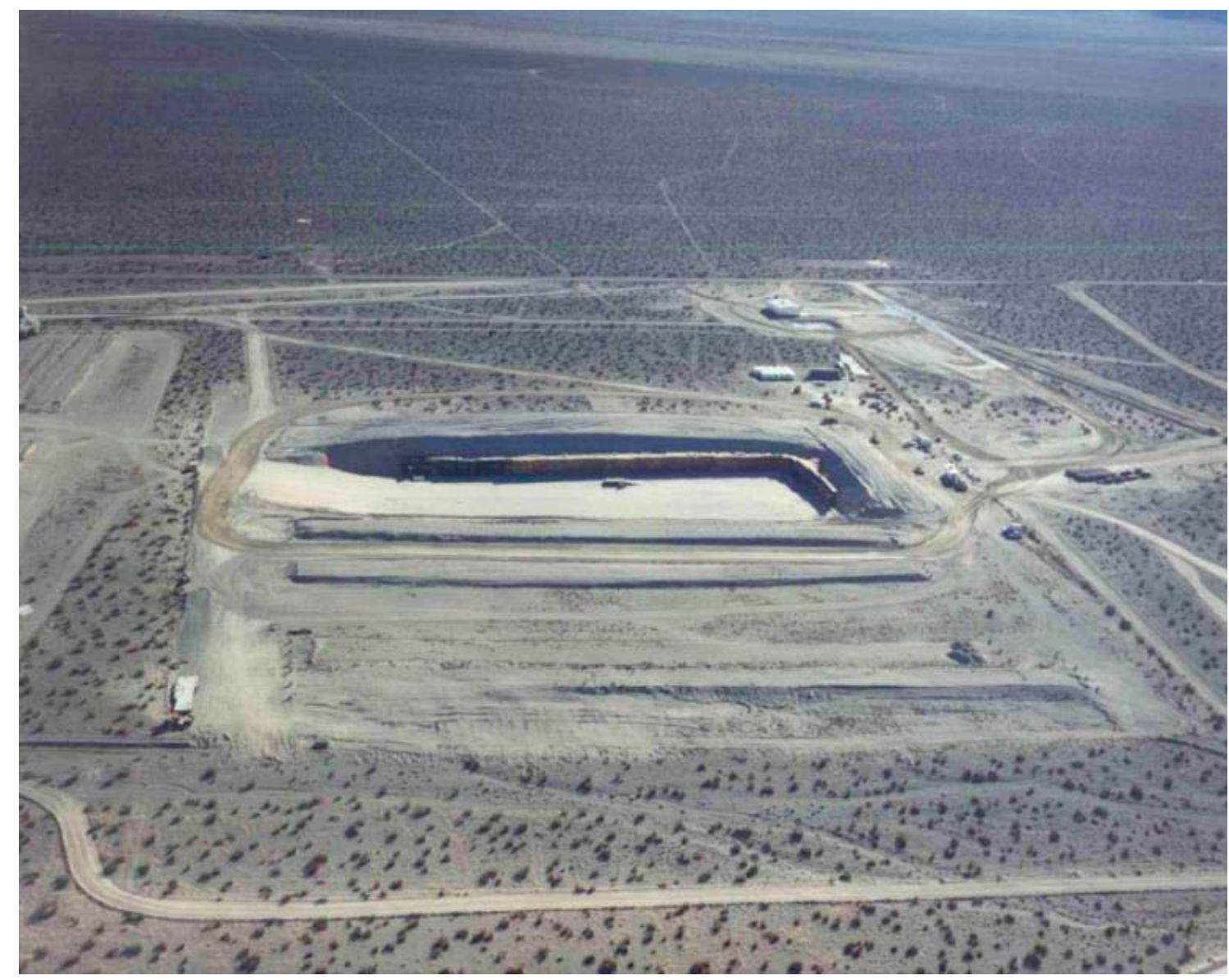

Figure 1. Nevada National Security Site Disposal Facility

\subsection{DOE RADIOACTIVE WASTE DISPOSAL POLICY}

U.S. Department of Energy Order DOE O 435.1, “Radioactive Waste Management," states that waste should be treated at the site at which it was generated, if practical, and if not, it should be treated at another DOE site. This policy reflects DOE's desire to develop adequate treatment capacity within its own system so that fluctuations in the commercial treatment markets do not significantly affect DOE's ability to generate, treat, and dispose of wastes from ongoing or planned projects. Development of mixed waste treatment capacity at the NNSS Disposal Facility is fully consistent with DOE policy and will enable the NNSS Disposal Facility and other DOE generators to utilize DOE treatment capability for many waste streams. Commercial treatment and disposal capacity will still be necessary for the many DOE waste streams that will not meet the NNSS Disposal Facility's waste acceptance and treatment criteria.

\section{POTENTIAL TREATMENT TECHNOLOGIES}

\subsection{SUMMARY SCREENING OF TECHNOLOGIES}

This section provides a brief listing of the potential treatment technologies that may be applicable for treating the MLLW types forecasted for disposal at the NNSS Disposal Facility. These potential treatment technologies are based on the technologies given in the regulations for meeting LDRs. Technologies for 
waste treatment are given in Title 40 Code of Federal Regulations (CFR) Part 268.42 and alternative technologies for debris wastes given in 40 CFR 268.45.

After looking at historical and forecasted waste streams and treatment types in Section 3 of this report, specific treatment technologies that may be practical at the NNSS Disposal Facility will then be recommended in Section 4. Potential RCRA LDR treatment technologies are summarized in Table 1.

Table 1. Potential LDR Treatment Technologies for MLLW and Debris

\begin{tabular}{|l|l|}
\hline \multicolumn{2}{|c|}{ Land Disposal Restriction Treatment Technologies Screened } \\
\hline Amalgamation & Macroencapsulation \\
\hline Thermal desorption & Microencapsulation \\
\hline Physical extraction & Mercury retorting \\
\hline Gas venting & Metals/inorganic recovery \\
\hline Biodegradation & Organics recovery \\
\hline Carbon adsorption & Zinc smelting \\
\hline Chemical oxidation/reduction & Stabilization \\
\hline Combustion/thermal recovery & Steam stripping \\
\hline Deactivation & Wet air oxidation \\
\hline Fuel substitute & Controlled reaction \\
\hline Vitrification & Chemical extraction \\
\hline Lead smelting & Thermal extraction \\
\hline Liquid extraction & Biological destruction \\
\hline Neutralization & Chemical destruction \\
\hline Polymerization & Thermal destruction \\
\hline Precipitation & Sealing \\
\hline
\end{tabular}

\subsection{MACROENCAPSULATION, STABILIZATION, AND MICROENCAPSULATION}

The use of the terms macroencapulsation, stabilization, and microencapsulation to describe specific treatment technologies varies in this evaluation. In some cases, the reports used as data for Section 3 combined macro- and microencapsulation; therefore, the data in Section 3 are stated as macro/microencapsulation for one category and stabilization as another. However, from Section 4 forward, the evaluation combines stabilization and microencapsulation as one treatment technology because of actual regulatory definitions.

The definition of macroencapsulation as provided by 40 CFR 268.45 and 268.42 states that either a waste or waste debris can be subject to macroencapsulation. The definition specifies that macroencapsulation is a coating of the waste/debris using resins, plastics, or cementatious materials.

Conversely, the definition of stabilization (40 CFR 268.42) indicates that it is applicable to waste streams and specifically limits its main ingredients to cementatious materials (e.g., Portland cement or pozzolans). Microencapsulation (40 CFR 268.45) is stabilization applied to waste debris and is also limited to 
cementatious materials. Stabilization and microencapsulation are the same technology applied to different waste forms. In Section 4 and beyond, stabilization and microencapsulation will be viewed as the same technology for the sake of technology selection and design/construction estimates.

\section{MLLW VOLUMES BY TECHNOLOGY EVALUATION}

This section of the evaluation looks at the waste volumes and treatment types for wastes previously disposed at the NNSS Disposal Facility and those projected to be disposed at the NNSS Disposal Facility. The data indicated two treatment types constituted a significant portion of the waste streams: macro/microencapsulation and stabilization. Based on median range numbers, a projected annual average volume of approximately 73,664 cubic feet $\left(\mathrm{ft}^{3}\right)$ per year of MLLW will need macro/microencapsulation or stabilization treatment for future disposal at the NNSS Disposal Facility.

The treatment volumes by the two major treatment types, as derived from Tables 3 and 4, are summarized in Table 2 below.

Table 2. Historical and Projected MLLW Volumes for the Two Major Treatment Types

\begin{tabular}{|c|c|c|c|}
\hline Technology & $\begin{array}{c}\text { Total } \\
\text { Historical Waste } \\
\text { Volume }\left(\mathrm{ft}^{3}\right) \\
(\mathbf{2 0 0 6 - 2 0 0 9 )}\end{array}$ & $\begin{array}{c}\text { Total } \\
\text { Projected Range } \\
\text { Median Value* }\left(\mathrm{ft}^{3}\right) \\
(\mathbf{2 0 1 0 - 2 0 1 6 )}\end{array}$ & $\begin{array}{c}\text { Average } \\
\text { Projected Average } \\
\text { Annual Volume }\left(\mathrm{ft}^{3}\right) \\
(2010-2016)\end{array}$ \\
\hline $\begin{array}{l}\text { Macroencapsulation/ } \\
\text { Microencapsulation }\end{array}$ & 114,273 & 464,950 & 66,421 \\
\hline Stabilization & 19,680 & 50,700 & 7,243 \\
\hline Totals & 133,953 & 515,650 & 73,664 \\
\hline
\end{tabular}

Sections 3.1 and 3.2 and Appendix A provide more details on historical and projected waste volumes and treatment types.

\subsection{HISTORICAL MLLW VOLUMES}

National Security Technologies, LLC, the prime contractor operating the NNSS Disposal Facility, supplied the data regarding historical treatment types and volumes.

This information is summarized in Table 3, which indicates the volumes by treatment type for the last four years. 
Table 3. Historical Treatment Types for MLLW Disposed at the NNSS Disposal Facility 2006-2009

\begin{tabular}{|l|r|}
\hline \multicolumn{1}{|c|}{ Technology Type } & Treatment Volume Total (ft' $\left.{ }^{3}\right)$ \\
\hline No sorption or solidification & 136,383 \\
\hline $\begin{array}{l}\text { Other - Waste lock, Aquadox, } \\
\text { Multizorb, VTD Residue }\end{array}$ & 22,672 \\
\hline Macro & 114,273 \\
\hline $\begin{array}{l}\text { Meets Concentration based LDR } \\
\text { standards }\end{array}$ & 1,741 \\
\hline Stabilization & 19,680 \\
\hline $\begin{array}{l}\text { Other (Provide LDR specific } \\
\text { Treatment Technology Code) }\end{array}$ & 295 \\
\hline $\begin{array}{l}\text { Meets Concentration based LDR, } \\
\text { Multizob, solidification, Macro, LDPE }\end{array}$ & 3,699 \\
\hline Amalgamation & $\mathbf{2 9 9 , 5 3 2}$ \\
\hline Total Waste Volume (ft ${ }^{3}$ ) & \\
\hline $\begin{array}{l}\text { LDPE = Low density polyethylene } \\
\text { VTD = vacuum thermal desorption }\end{array}$ & \\
\hline
\end{tabular}

\subsection{PROJECTED MLLW VOLUMES}

Using two waste disposition forecasts provided to DOE by numerous governmental entities (e.g., national laboratories), the quantity of waste that could require treatment at the NNSS Disposal Facility from 2010 to 2016 was estimated to range from $61,800 \mathrm{ft}^{3}$ to $951,600 \mathrm{ft}^{3}$, or on average from $8,800 \mathrm{ft}^{3}$ to $135,900 \mathrm{ft}^{3}$ annually. The first forecast used for this projection included a database of different waste types and quantities where the NNSS Disposal Facility was identified as the disposal facility (“ToNNSS”). The second waste forecast used included similar information for wastes where the disposal facility had not been determined ("ToTBD”). The prescribed treatment methods of either macroencapsulation or stabilization/solidification were listed on these forecasts for some of the wastes; where not prescribed, assumptions were made on the treatment method(s) to be utilized.

The results of this exercise are summarized in Table 4 .

Table 4. Projected Waste Volumes for MLLW to be Disposed at the NNSS Disposal Facility 2010-2016 by Treatment Type

\begin{tabular}{|l|r|}
\hline \multicolumn{1}{|c|}{ Treatment Type } & Waste Quantity Range $\mathbf{( f t}^{3}$ ) \\
\hline Macro/microencapsulation & 54,000 to 858,000 \\
\hline Stabilization & 7,800 to 93,600 \\
\hline Total Waste Volume (ft $\left.{ }^{3}\right)$ & $\mathbf{6 1 , 8 0 0}$ to $\mathbf{9 5 1 , 6 0 0}$ \\
\hline
\end{tabular}

A more detailed table generated from the two waste disposition forecasts is included in Appendix A. Due to the projected small quantity ( $\sim 1$ liter/year) of elemental mercury mixed waste to be received at the NNSS Disposal Facility, the treatment of this waste stream is not reflected in Table 4 or the accompanying table in Appendix A. 


\title{
4. SELECTION OF POTENTIAL TREATMENT TECHNOLOGIES
}

\author{
4.1 TREATMENT ACTIVITIES FROM HISTORICAL EXPERIENCE
}

After interviews and conversations with personnel operating the NNSS Disposal Facility, it was found that three specific activities that could be considered treatment should be included in any discussion of RCRA-permitted treatment activities. These treatment activities include sorting and segregation of wastes, amalgamation of small quantities of MLLW mercury, and use of the UltraTech Macro Box ${ }^{\circledR}$ as backup to macroencapsulation. Although sort and segregation may not be considered an actual treatment technology, it is viewed as a RCRA Part B permitted activity when conducted away from the waste generator's site. These three treatment activities have been identified as selected treatment technologies based on historical experience.

\section{Sorting and Segregation Alternative}

Historical experience at the NNSS Disposal Facility has shown that significant reductions in the amount of waste to be disposed of and/or the amount of waste needing treatment can be achieved through the sorting and segregating of wastes after they have been received. Having a "sort and segregate" alternative allows waste containers, especially legacy waste containers, to be opened and the wastes sorted and segregated into streams that require further treatment and those that do not require any treatment. This would greatly reduce the volume of wastes requiring treatment and subsequently requiring disposal in the RCRA permitted disposal facility at the NNSS Disposal Facility.

\section{Bench-Scale Amalgamation}

Historically, small quantities of MLLW liquid mercury have been found in things such as vials, switches, and thermostats during sort and segregation operations. These small quantities of MLLW mercury are difficult to dispose of because they require trans-shipping to an offsite facility for further treatment prior to being shipped back to the NNSS Disposal Facility for disposal. The ability to treat small quantities of MLLW liquid mercury by the process of bench-scale amalgamation would eliminate offsite shipping and treatment.

\section{$\underline{\text { UltraTech Macro Box }^{\circledR}}$}

The UltraTech Macro Box ${ }^{\circledR}$ is a macroencapsulation system composed of high-density polyethylene (HDPE)/linear low-density polyethylene (LDPE) macro-liners housed within the NNSS Disposal Facility Waste Acceptance Criteria-compliant stainless steel boxes. These containers also meet RCRA LDRs for macroencapsulation. Although cost prohibitive for repetitive use, the containers are a patented technology with existing design specifications, and their use could be included in a RCRA treatment permit application with very little additional effort. As a result of little additional permitting effort, these boxes could provide an emergency or alternative form of macroencapsulation for waste debris that cannot be readily treated with Portland cement. An example would be waste streams with higher activity in which as low as reasonably achievable principles would potentially drive use of the macro box technology.

\subsection{SELECTION OF POTENTIAL TREATMENT TECHNOLOGIES}

In Section 2 of this evaluation, the potential treatment technologies available were listed; in Section 3 the treatments' historical and projected waste volumes were compared. This comparison found that macro/microencapsulation and stabilization composed the two most significant waste volumes and treatment technologies used and projected to be used at the NNSS Disposal Facility. In addition, historical 
experience at the site has indicated that sort and segregation and amalgamation of mercury on a small scale would be complementary to the encapsulation and stabilization technologies.

The following treatment technologies are recommended for installation at the NNSS Disposal Facility:

- Macroencapsulation

o Portland cement

o UltraTech Macro Boxes ${ }^{\circledR}$

- Stabilization/Microencapsulation

o Portland cement

- $\quad$ Sort and Segregation

- Bench-scale Mercury Amalgamation

The following list provides some examples of the specific treatment technologies and approaches for implementations which were initially screened for applicability to the waste streams and for installation at the NNSS Disposal Facility:

\section{Macroencapsulation}

- Grouting in carbon-steel boxes or drums

- Welded stainless steel containers

- UltraTech Macro Boxes ${ }^{\circledR}$

- High integrity containers

- Portland cement and fly ash - Numerous

- Pozzolan (Chemfix Technologies Inc.)

- Chemically bonded Phosphate Ceramic Encapsulation

- Polyethylene encapsulation (LDPE and HDPE)

o LDPE - single screw extractor (EnergySolutions)

o HDPE - Pre-manufactured containers (Chemical Waste Management Inc., BOH Environmental LLC, and Ultra-Tech International Inc.)

- Asphalt (cold/hot mix)

- Thermosetting Resin (polyester and epoxy)

- Synthetic Elastomers (rubber)

- Ceramic silicone foam (Orbit Technologies)

- Dolocrete $^{\mathrm{TM}}$ (calcined dolomitic binder material)

- Sulfur Polymer Cement (Newmont Mining Corp)

\section{Microencapsulation}

- Polyethylene encapsulation (LDPE and HDPE)

o LDPE - single screw extractor (EnergySolutions)

o HDPE - Pre-manufactured containers (Chemical Waste Management Inc., BOH Environmental LLC, and Ultra-Tech International Inc.)

- Portland cement and fly ash - Numerous

\section{Stabilization}

- Portland cement and fly ash - Numerous 
Amalgamation - Bench-scale application

- Sulfur polymer stabilization/solidification

- Mixing with sulfur and small amounts of inorganic agents to stabilize mercury

A brief literature review of these specific technologies and an informal survey of two of the industries' largest existing treatment facilities determined the two treatment technologies that could most cost-effectively be applied at the NNSS Disposal Facility for encapsulation and stabilization would be the use of Portland cement or polyethylene resins.

\section{Portland Cement vs. Polyethylene Resin}

Portland cement and polyethylene macroencapsulation both offer many technological and economic advantages:

- Extruders and pugmills (cement mixers) are commercially available and have a long history of industrial use.

- The equipment and materials used in the processes are available off the shelf, except for specialized pour nozzles.

- Both technologies can be scaled or tailored to site-specific conditions and can be readily incorporated into existing facilities.

- The processes operate at low temperatures and need no off-gas treatment.

- Both media are commonly used and relatively inexpensive compared to other treatment processes.

- Both can be formulated to produce a waste barrier that is durable, leach resistant, and compliant with Nuclear Regulatory Commission guidelines and RCRA requirements for disposal of MLLW.

\section{Selection of Portland Cement}

Although polyethylene resin is extremely tough and flexible, has excellent chemical resistance, is easy to process, and is used at the two major MLLW commercial treatment facilities, Portland cement has been recommended for installation at the NNSS Disposal Facility for the following reasons:

- An operating cement batch plant is already constructed on site near the NNSS Disposal Facility.

- Portland cement qualifies as an accepted media for both macroencapsulation and stabilization/microencapsulation.

- Using an existing portable cement mixing truck, Portland cement could be used with a methodology that is approved by the regulators on a case-by-case basis, for performing macroencapsulation of large debris in place within the landfill cell.

\section{Amalgamation of Elemental Mercury Mixed Waste}

As noted above, approximately 1 liter/year of elemental liquid mercury mixed waste is projected during the mixed waste sort and segregation activities at the NNSS Disposal Facility. For this small quantity of waste, the NNSS Disposal Facility could use bench-scale equipment to carry out the amalgamation/ stabilization treatment. From a review of technical publications that address treatment of radiologically contaminated elemental mercury, and discussions with RCRA treatability laboratory personnel who have direct experience with treating this type of waste, two viable methods of treating elemental mercury mixed waste on a bench scale, which can result in a waste material being disposed in accordance with the U.S. Environmental Protection Agency (EPA) land disposal restrictions, include: 
1. Mercury Amalgamation - Physical mixing of the waste liquid elemental mercury with a metallic compound (typically powdered sulfur) at room temperature resulting in formation of a stable mercury non-liquid compound, such as mercury sulfide. Additional chemical additives in relative small percent quantities are required to be mixed with the reacted mercury mixture to render it suitable for land disposal. The mercury amalgamation reaction is exothermic and will result in the evolution of some mercury-containing air emissions.

2. Sulfur Polymer Stabilization/Solidification (SPSS) - Physical mixing of the waste liquid elemental mercury with a powdered sulfur polymer cement to form a stable mercury sulfide compound, followed by heating to melt the compound while mixing. The mixture is then cooled to form a monolithic solid waste in which the stabilized mercury particles are microencapsulated within a sulfur polymer matrix, rendering this solid waste suitable for land disposal. This process was developed at Brookhaven National Laboratory.

Both elemental mercury treatment methods listed above involve evolution of mercury-containing emissions that are generated during treatment; therefore, at a minimum, the treatment would need to be performed under a laboratory fume hood. The mercury amalgamation requires only bench-scale mixing equipment, whereas the SPSS treatment method requires the reaction vessel to be placed under an inert gas atmosphere and be capable of heating the contents to approximately $130^{\circ} \mathrm{C}$. To avoid the need for inert gases and heating devices, the bench-scale mercury amalgamation method is recommended for installation at the NNSS Disposal Facility within the Visual Examination and Repackaging Building (VERB).

Two key factors have been found to significantly impact the success of elemental mercury mixed waste treatment systems to yield a stabilized material that can meet EPA land disposal restrictions: (1) the presence of other inorganic contaminants in the liquid mercury and (2) the consistency of the mercury waste stream's composition. These are factors to consider in establishing waste acceptance criteria for elemental mercury mixed waste, and in arriving at a treatment "recipe" that consistently results in meeting the treatment objectives.

\section{DESIGN, CONSTRUCTION, AND PERMITTING}

\subsection{DESIGN AND CONSTRUCTION REQUIREMENTS}

\section{Existing Facilities}

The first task in examining the potential design requirements was to look at existing facilities at the NNSS Disposal Facility. The use of existing facilities would greatly reduce both design and construction costs and would reduce the permitting timeframe because the design drawings already exist for inclusion in the permit application. Presently at the NNSS Disposal Facility, the following facilities exist that could be used in a treatment and storage process. The brief description of these facilities also includes comments regarding design and construction changes that may be required to support a treatment process.

- VERB - Visual Examination and Repackaging Building

- $\quad$ TP - Transuranic (TRU) Pad

- $\quad$ TPCB - TRU Pad Cover Building

- $\quad$ DHP - Drum Holding Pad

- Area 1 Cement mixing batch plant

- $\quad$ RTR - Real Time Radiography Building

- $\quad$ SIS - Sprung Instant Structure (covered with gravel edges) 
VERB - The VERB is a covered building, approximately $60 \times 80$ feet (ft), and contains a Permacon structure that is constructed to withstand negative air pressure with a curbed impervious floor. The air is currently emitted through a bank of HEPA filters. This structure could be used to perform treatments that may include sort and segregate, macro/microencapsulation, stabilization, and bench-scale amalgamation of elemental mercury. Air emission controls may have to be modified and permitted depending on the wastes accepted and treatment conducted. In addition, this area would need to be modified to include whatever process equipment is needed for the selected treatment technologies. For example, if treatment with a pozzolanic cement grout were selected, a pugmill mixer would be needed to keep the grout mix from setting up, and a grout pump/delivery system would need to be installed to transfer the grout to the treatment area within the VERB.

TP and TPCB - The TRU Pad is a large asphalt covered and bermed pad approximately 150 by $300 \mathrm{ft}$ that was constructed to meet the engineering requirements for MLLW storage. The TPCB is an enclosed, soft sided building supported by a metal superstructure, which covers approximately one-half of the TRU Pad area. This building is currently used to stage wastes in an enclosed environment out of the weather. The TRU Pad and TPCB were constructed to meet RCRA engineering requirements and offer ample room to stage and store wastes prior to treatment and/or prior to disposal. Little or no construction activities would be required to include the areas for waste storage within a treatment process permit.

DHP - The Drum Holding Pad is a smaller (20 by $40 \mathrm{ft}$ ) cement bermed and covered pad that is currently used to accumulate drummed waste prior to being sent off site for disposition. This pad could also be included in an application for onsite treatment with little or no engineering or construction costs. This pad could be used to store smaller quantities of waste drums that may need to be stored separately from other waste streams.

Area 1 Cement Mixing Batch Plant - This existing plant, which is located on the NNSS Disposal Facility, but separate from the NNSS Disposal Facilities area, could be used to develop and mix a pozzolanic grout that would meet the requirements for treatment technologies such as stabilization and macro/microencapsulation. The existing fleet of mixer trucks could be used to deliver the grout to the pugmill at the VERB. Since this facility is not involved in the treatment process, but only delivers a product for the treatment, it would not need to be included in permit for MLLW treatment and would not represent any design or construction costs.

SIS and RTR - Other structures located at the NNSS Disposal Facility, such as the SIS and the RTR, could be used to support a treatment process, but at present would require specific engineering upgrades in order to meet requirements. The SIS, a soft-sided enclosed building, currently does not have an impermeable floor or berm, which would be required and most likely would be used to store waste. The RTR's usable area is largely occupied by the radiography unit at the present time and would require significant modification to enlarge the building to obtain any usable area. Unless radiography is found to be a necessary step in the treatment process, the RTR should not be considered under a permit for MLLW treatment.

\section{Design and Construction Requirements}

Even if the existing structures and their existing design drawings are used, some portions of the treatment process would require the development of design drawings and treatment process specifications and the associated construction of the newly designed treatment processes. Table 5 identifies some of the design requirements and ensuing construction activities for the proposed treatment technologies. 
Table 5. Design Requirements Utilizing Existing Facilities at the NNSS Disposal Facility

\begin{tabular}{|c|c|c|c|}
\hline Existing Facility & Macro/Micro & Amalgamation & Storage \\
\hline \multirow{4}{*}{ VERB } & $\begin{array}{l}\text { Cement pad and cover for } \\
\text { material delivery and base } \\
\text { for material preparation } \\
\text { system (i.e., pugmill pad) }\end{array}$ & $\begin{array}{l}\text { Bench-scale area } \\
\text { amalgamation process and } \\
\text { specifications for meeting } \\
\text { LDR treatment standards }\end{array}$ & None \\
\hline & $\begin{array}{l}\text { Material preparation system } \\
\text { design and specifications for } \\
\text { meeting LDR treatment } \\
\text { standards (i.e., HDPE } \\
\text { heating system or grout } \\
\text { pugmill mixing system) }\end{array}$ & Ventilation hood design & \\
\hline & $\begin{array}{l}\text { Material delivery system } \\
\text { inside building to the } \\
\text { treatment area (i.e., piping, } \\
\text { hoses, nozzles) }\end{array}$ & $\begin{array}{l}\text { Air emission control } \\
\text { system modifications to } \\
\text { deal with mercury vapors }\end{array}$ & \\
\hline & $\begin{array}{l}\text { Waste suspension system } \\
\text { within containers to } \\
\text { accomplish } \\
\text { macroencapsulation }\end{array}$ & & \\
\hline ТP/ТPCB & None & None & $\begin{array}{l}\text { Calculations of } \\
\text { maximum waste } \\
\text { volumes in consideration } \\
\text { of waste codes and } \\
\text { treatment volumes }\end{array}$ \\
\hline DHP & None & None & $\begin{array}{l}\text { Calculations of } \\
\text { maximum waste } \\
\text { volumes in consideration } \\
\text { of waste codes and } \\
\text { treatment volumes } \\
\end{array}$ \\
\hline $\begin{array}{l}\text { Area } 1 \text { Cement } \\
\text { Plant }\end{array}$ & None & None & None \\
\hline $\begin{array}{l}\text { DHP = Drum Hol } \\
\text { TP/TPCB = TRU } \\
\text { VERB = Visual E }\end{array}$ & $\begin{array}{l}\text { ing Pad } \\
\text { ad/TRU Pad Cover Building } \\
\text { amination and Repackaging E }\end{array}$ & ing & \\
\hline
\end{tabular}

\subsection{PERMITTING REQUIREMENTS}

\section{Permitting Approach}

Currently, the NNSS Disposal Facility holds a RCRA Part B permit for the landfill disposal of MLLW from the Nevada Division of Environmental Protection (NDEP). This permit only allows for the direct disposal of wastes that must be received in a RCRA LDR-compliant form.

The permitting structure could be changed in one of two ways:

1. Major modification of the existing permit to include treatment of MLLW and its associated storage.

2. Issuance of a separate stand-alone permit for the treatment of MLLW and its associated storage. 
With either approach, the permitting process will require the same steps and take approximately the same time to conduct.

\section{Significant Permitting Elements}

Beyond selection of the actual treatment technologies, the following three elements will be significant in preparing the permit application. These elements may require substantial input from outside sources, such as vendors for the treatment specifications, generators for the waste acceptance criteria, and NDEP for the waste analysis plan. The following three elements and their impacts have been incorporated into the schedule estimate:

- Development of specific Waste Acceptance Criteria will mandate the shipment and receipt only of waste streams that can be successfully treated by the selected technologies.

- Determining and incorporating the treatment technologies specifications to demonstrate that the treatment technology can meet LDR treatment requirements.

- Development of the Waste Analysis Plan, which will specify the sampling and analysis, will need to be performed on treated wastes in order to verify the treatment has met LDR requirements prior to disposal.

\subsection{ESTIMATED DESIGN, PERMITTING, AND CONSTRUCTION SCHEDULE}

This section provides an estimated schedule for the design, permitting, and construction activities associated with the installation of the Portland cement and bench-scale amalgamation technologies at the NNSS Disposal Facility. The schedule indicates that these tasks could be completed in an estimated 20 month design, permitting, and construction timeline.

The schedule is based largely upon previous field experience with similar projects and contains these assumptions:

- Significant reduction in application preparation time can be achieved by utilizing sections of the existing Part B landfill permit.

- $\quad$ The NDEP review time will be only 75 days.

- Significant public comment for the purpose of delaying the application will not be given.

- Construction contractors' access onto the secure the NNSS Disposal Facility will not be delayed. 
APPENDIX A

COMBINED PROJECTED WASTE VOLUMES 


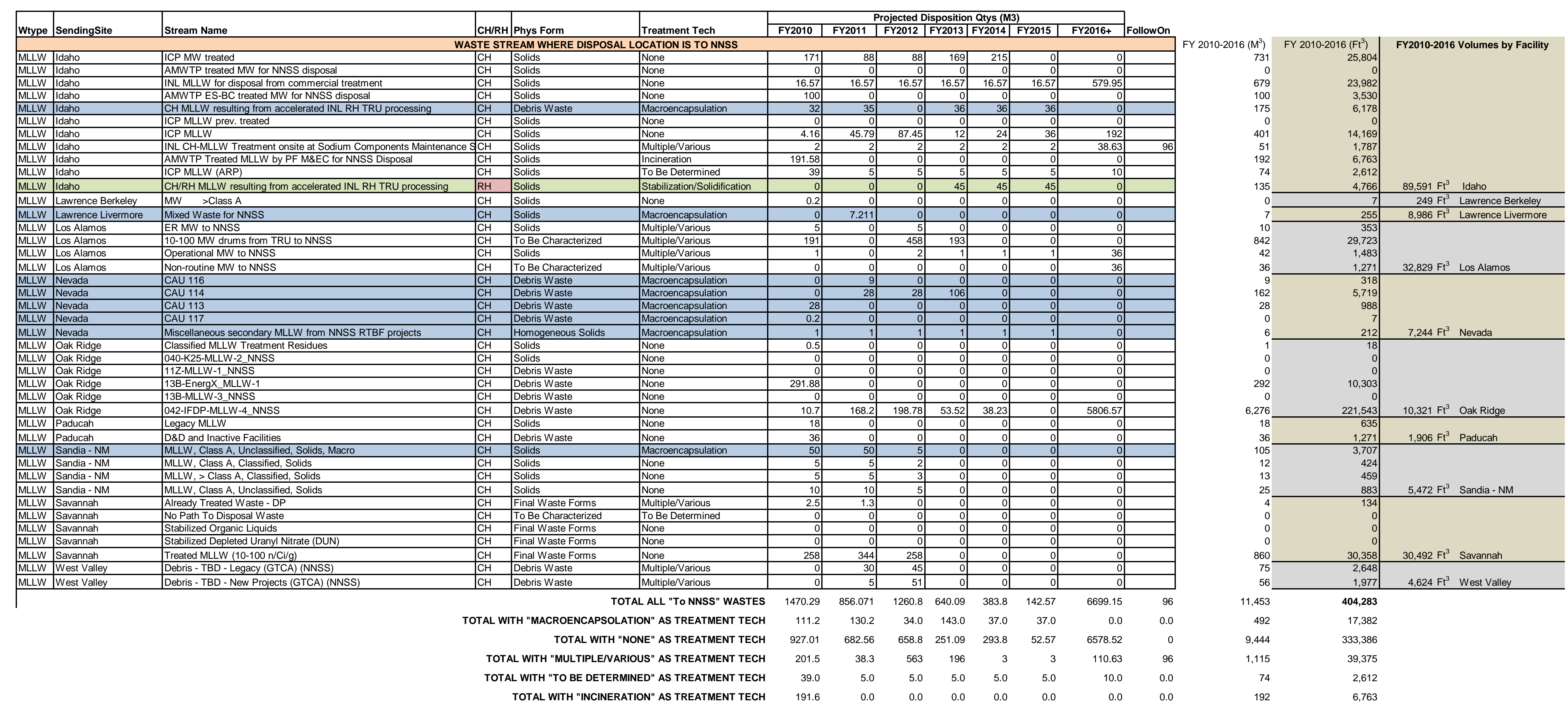




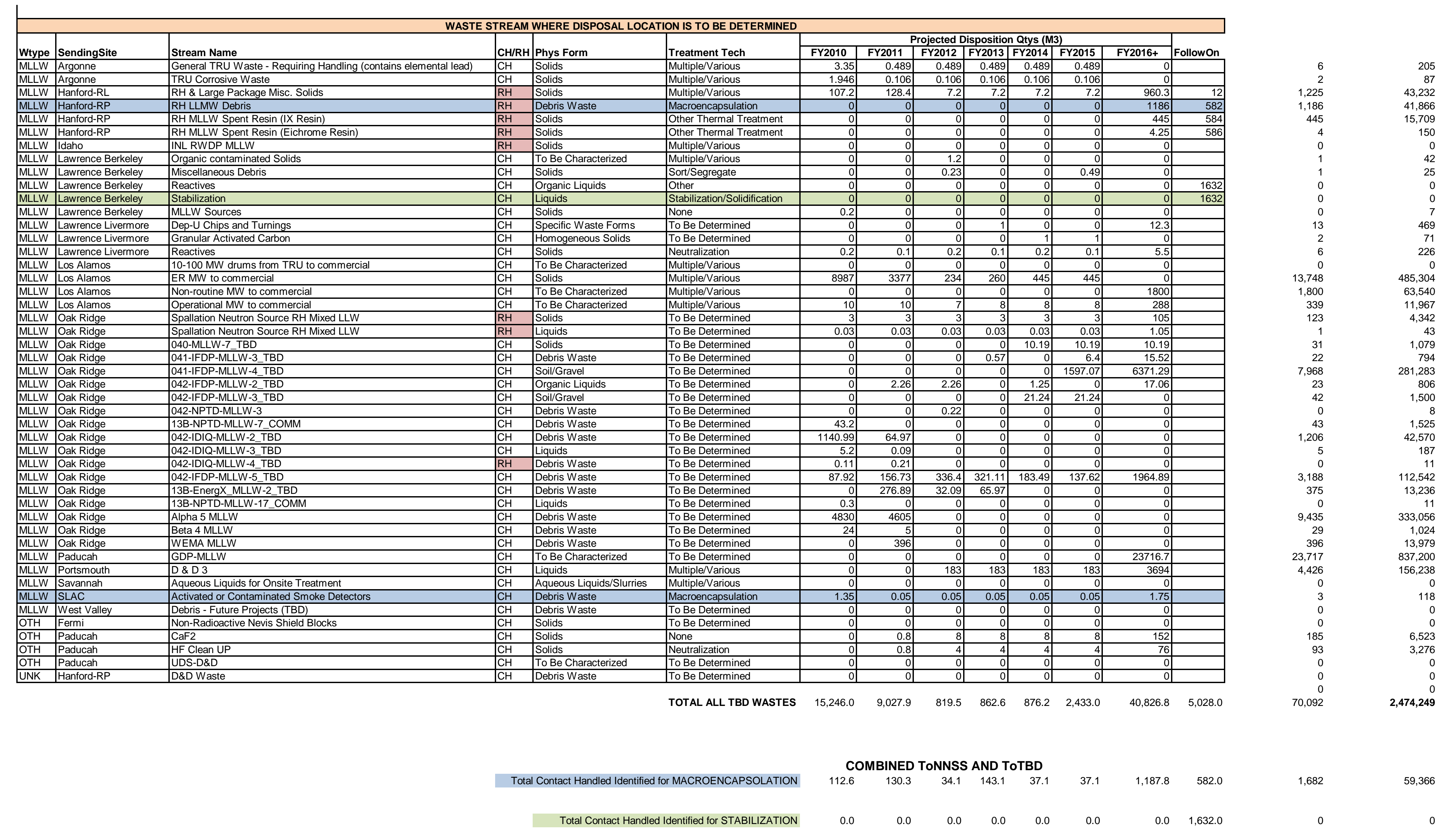




\section{Combined Projected MLLW Volumes}

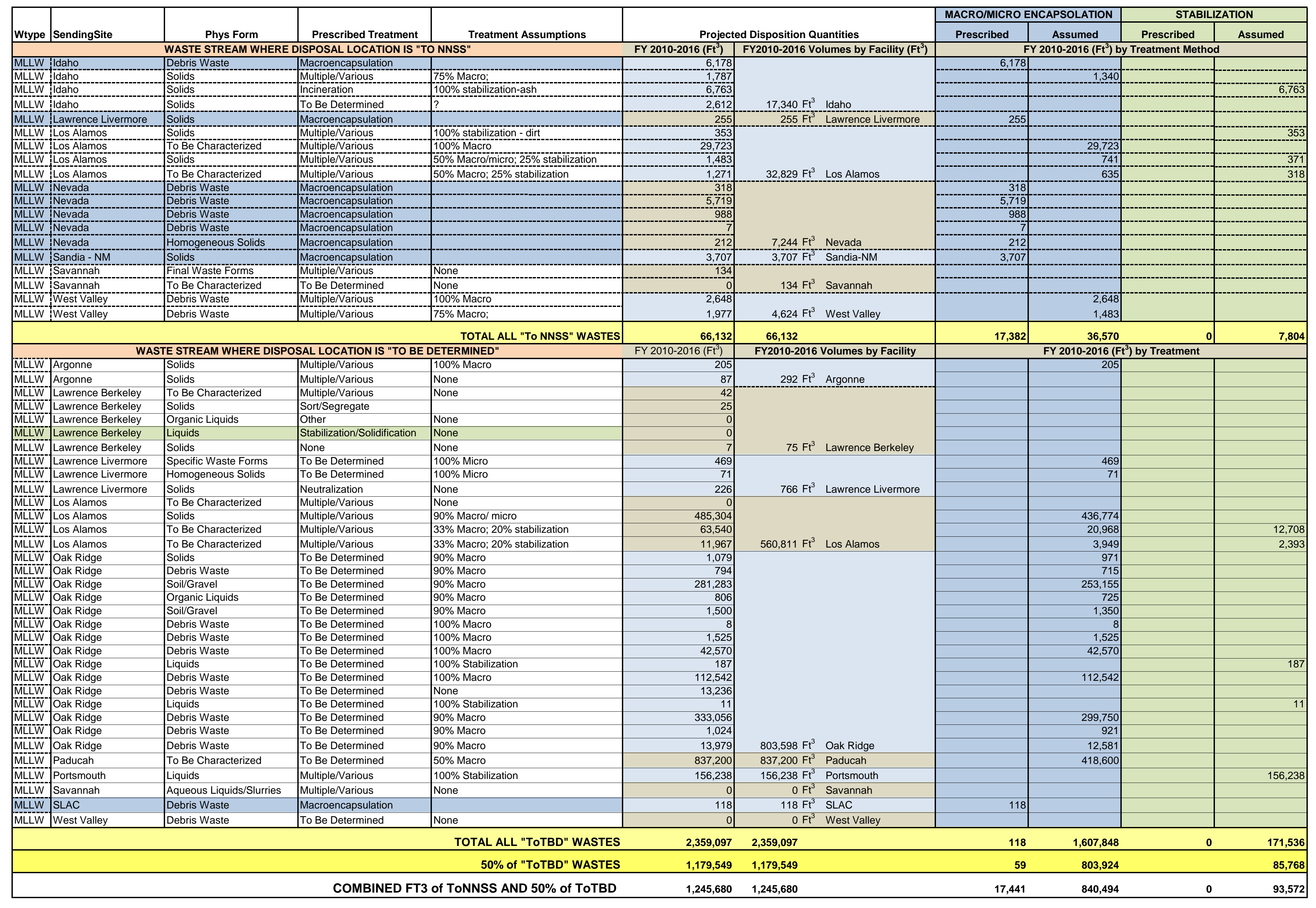

